\title{
STUDIES IN THE SYSTEMATICS OF MEXICAN AND TEXAN GRINDELIA (ASTERACEAE: ASTEREAE)
}

\author{
Guy L. Nesom \\ Department of Botany, University of Texas, Austin, Texas 78713 U.S.A.
}

\begin{abstract}
Four new species of Grindelia are described from México, G. hintoniorum Nesom, G. macvaughii Nesom, G. turneri Nesom and G. vetimontis Nesom. Three varieties are recognized within G. microcephala DC.: var. microcephala, var. adenodonta Steyerm. and var. pusilla Steyerm. Grindelia microcephala var. montana Steyerm. is elevated in rank to G. oaxacana Nesom, nom. et stat. nov. Grindelia nuda Alph. Wood is recognized as a species separate from $G$. squarrosa (Pursh) Dunal and G. aphanactis Rydb. is considered to be conspecific with $G$. nuda, reduced in rank to G. nuda var. aphanactis (Rydb.) Nesom, comb. et stat. nov. Grindelia oxylepis E. Greene var. eligulata Steyerm. is raised to specific rank as G. eligulata (Steyerm.) Nesom, comb. et stat. nov. Grindelia neomexicana Woot. \& Standl. (G. scabra E. Greene var. neomexicana [Woot. \& Standl.] Steyerm.) is treated as G. arizonica A. Gray var. neomexicana (Woot. \& Standl.) Nesom, comb. nov. and the concept of G. arizonica is further broadened by including populations from México and Texas. Grindelia greenei Steyerm. is treated as G. lanceolata Nutt. var. greenei (Steyerm.) Nesom, comb. et stat. nov. Four varieties are recognized within $G$. inuloides Willd.: var. glandulosa (Greenm.) Steyerm., var. hirtella (Robinson \& Greenm.) Nesom, comb. nov., var. inuloides and var. latamplexa Nesom, var. nov. The identities and geographic distributions of $G$. scabra E. Greene, G. havardii Steyerm., G. nelsonii Steyerm. and G. subdecurrens DC. are clarified.
\end{abstract}

KEY WORDS: Grindelia, Asteraceae, Astereae, Texas, México.

The North American species of Grindelia were the subject of a monographic treatment by Steyermark (1934), who provided many valuable insights regarding the group, particularly with regard to nomenclature and types. The genus has remained poorly understood however, and plants are difficult to identify using Steyermark's keys and descriptions. Further, at the time of his 
study, available specimens could give only a very general idea of the geographic range of the species recognized. The present study, undertaken in connection with forthcoming taxonomic treatments of the Asteraceae for México and for Texas (Turner \& Nesom, in prep.), attempts to clarify a number of problems that have remained. The following taxonomic evaluations and clarifications, nomenclatural adjustments, and descriptions of new taxa should be helpful in providing at least a firmer base for future investigations of the genus.

\section{THE GRINDELIA NUDA-APHANACTIS COMPLEX}

A population system of eradiate plants (Grindelia squarrosa [Pursh] Dunal var. nuda [Alph. Wood] A. (iray $\equiv G$. nuda Alph. Wood) occurs in north central Texas and adjacent New Mexico through southeastern Colorado and southwestern Kansas (Map 1). Radiate G. squarrosa, including the typical variety and several intergrading varieties, occupies a large geographic area from Montana and North Dakota southward to Texas and New Mexico. Variety nuda and typical $G$. squarrosa are largely allopatric, but radiate plants are scattered in the range of the eradiate populations. Besides the presence of ray flowers, at least the Great Plains forms of $G$. squarrosa differ from $G$. nuda in the production of dimorphic achenes: the ray and outer disc achenes of $G$. squarrosa are smooth and compressed but slightly 3-4 angled, while the inner disc achenes are longer than the outer, strongly compressed and 2 angled, and have numerous, superficial, longitudinal nerves; the achenes of $G$. nuda are monomorphic, all smooth or developing shallow furrows late in their maturation.

In view of their remarkable difference in achene morphology and their partial sympatry, which is suggestive of some degree of genetic isolation, I believe that $G$. squarrosa and $G$. nuda are appropriately regarded as separate species. The monomorphic achenes of $G$. nuda suggest that its relationships lie with G. oxylepis E. Greene, G. arizonica A. Gray, and other species with similar achenes. The Mexican species known to have dimorphic achenes are relatively few in number. Their geographic distributions are shown in Map 2 ( $G$. microcephala $D C$.), Map 3 ( $G$. lanceolata Nutt.) and Map 4 (the related pair $G$. tenella Steyerm. and (G. grandiflora Hook.).

Another relatively large population system of eradiate plants that has been regarded as a separate species, Crindelia aphanactis Rydb., forms with $G$. nuda, a complex that is best treated as a single species. The two taxa are morphologically very similar, of essentially continuous geographic range and intergrading over a large area where they meet. Grindelia aphanactis and $G$. nuda have been separated only by differences of degree, the most prominent difference being the relatively narrower leaf shape of $G$. aphanactis. Steyermark (1934: p. 492) added that "From narrow-leaved forms of G. squarrosa var. nuda, such as f. angustior. $G$. aphanactis may be distinguished by its more 
markedly serrulate or setulose-serrulate pappus awns, more strongly reflexed involucral bracts, more deeply ribbed or furrowed achenes, and less regularly crenulate-serrulate leaf margins." With respeci to these criteria noted by Steyermark, 1 find no consistent difference in pappus awns (strongly scabrousciliolate awns can be found in typical populations of both taxa) or in the position and morphology of the phyllaries, which are variably spreading-reflexed. In their typical appearances, on either side of the zone of intermediacy, G. nuda and $G$. aphanactis can be distinguished only by leaf morphology, although achenes of $G$. aphanactis have a tendency to become more deeply furrowed.

Steyermark (1934) cited specimens of both G. aphanactis and Grindelia squarrosa var. nuda from wesi Texas; Correll \& Johnston (1970) also recognized the occurrence of both taxa in Texas. Martin \& Hutchins (1981) recognized both taxa from eastern New Mexico, as did Harrington (1954) from southeastern Colorado. In contrast, in the Atlas of the Flora of the Great Plains (Great Plains Flora Assoc. 1977), G. aphanactis apparently was not considered apart from var. nuda, since only the latter was mapped from those states.

Typical Grindelia nuda occurs from central Texas north into western Kansas and southeastern Colorado. Typical G. aphanactis occurs in Arizona, New Mexico, and in southern Utah and Colorado. The plants of several collections from western Chihuahua have short spinulose (vs. glandular) foliar teeth but otherwise are like the species. There is a relatively wide area of morphological intermediacy between $G$. nuda and $G$. aphanactis in west Texas and eastern New Mexico. Steyermark's var. nuda forma angustior is also from this region. Map 1 shows the geographical range of the whole complex and the area of intermediacy.

Chromosome counts reported in the Grindelia nuda-aphanactis complex do not resolve the taxonomic problems, although the variability suggests that a further knowledge of chromosome numbers might contribute to a solution. Several populations of var. aphanactis from Arizona and northern New Mexico are tetraploid (Raven, et al. 1960; Dunford 1970; Kovanda 1972; Pinkava \& Keil 1977; Schaack 1983), but a diploid has been reported from El Paso Co., Colorado (Semple 1985, as G. squarrosa var. nuda). Both diploids and tetraploids have been reported from typical var. nuda $(n=12$, Whitaker \& Steyermark 1935, neither locality nor voucher ciied; $n=6$, Turner \& Ellison 1960). The localities of these counts are plotted on Map 1.

Grindelia nuda comprises two varieties, separated in their typical forms by the following couplet. The descriptions of each have been drawn from a range of plants outside of the area of intermediacy, where the identification of many of the intermediates is arbitrary. 


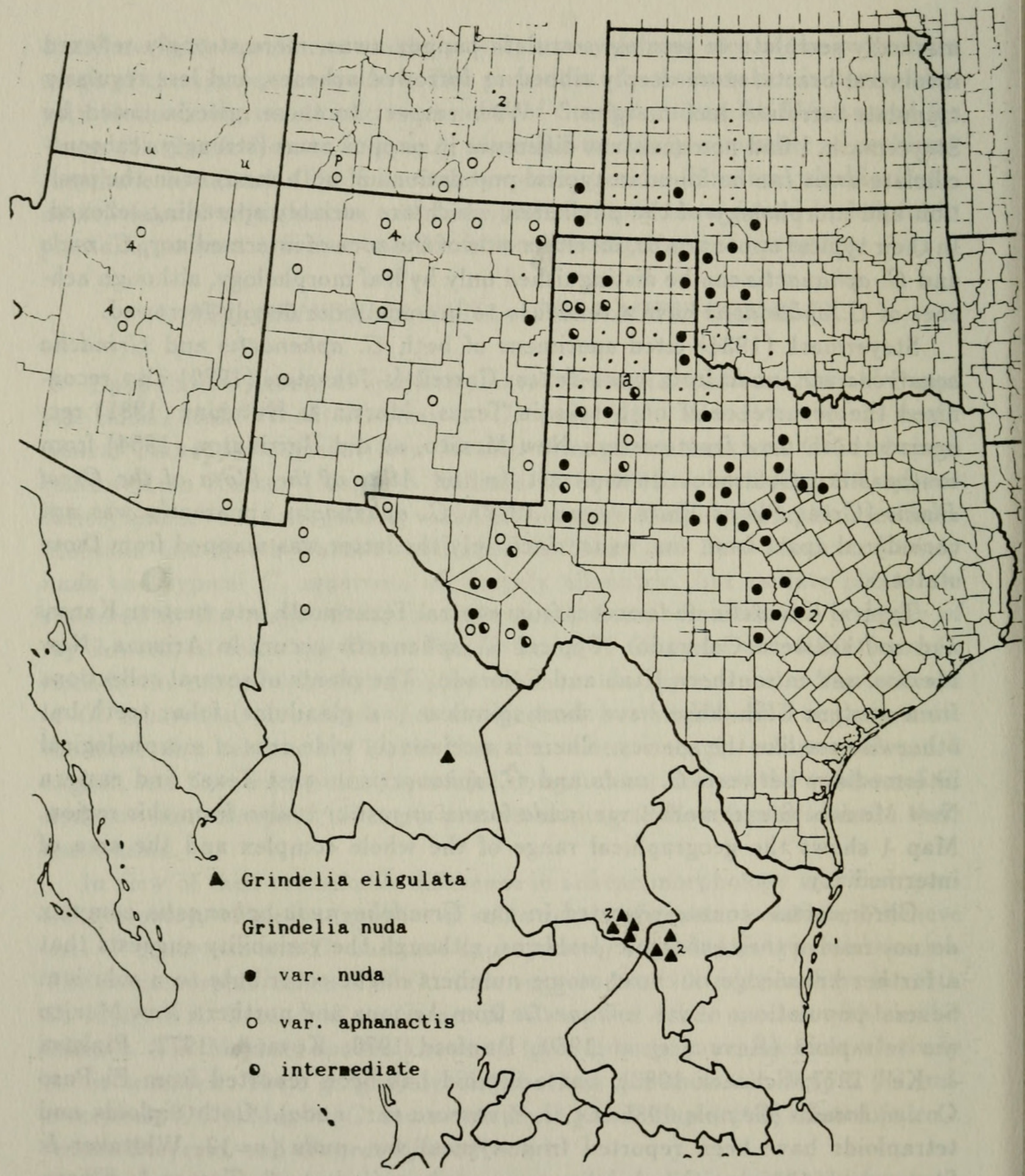

Map 1. Geographical range of Grindelia eligulata and Grindelia nuda sensu lato, showing var. nuda and var. aphanactis. The map is constructed from specimens in LL-TEX and SMU. The northern margins of the range are adjusted somewhat by records from the Atlas of the Flora of the Great Plains (Great Plains Flora Assoc. 1977), these shown as small dots. Records from Welsh (1983) are marked as "и"; the location of the type collection of G. pinnatifida Woot. \& Standl. is marked "p"; the locality of forma angustior is marked "a". Localities of diploid chromosome counts are marked "2"; those of tetraploid counts are marked "f". 


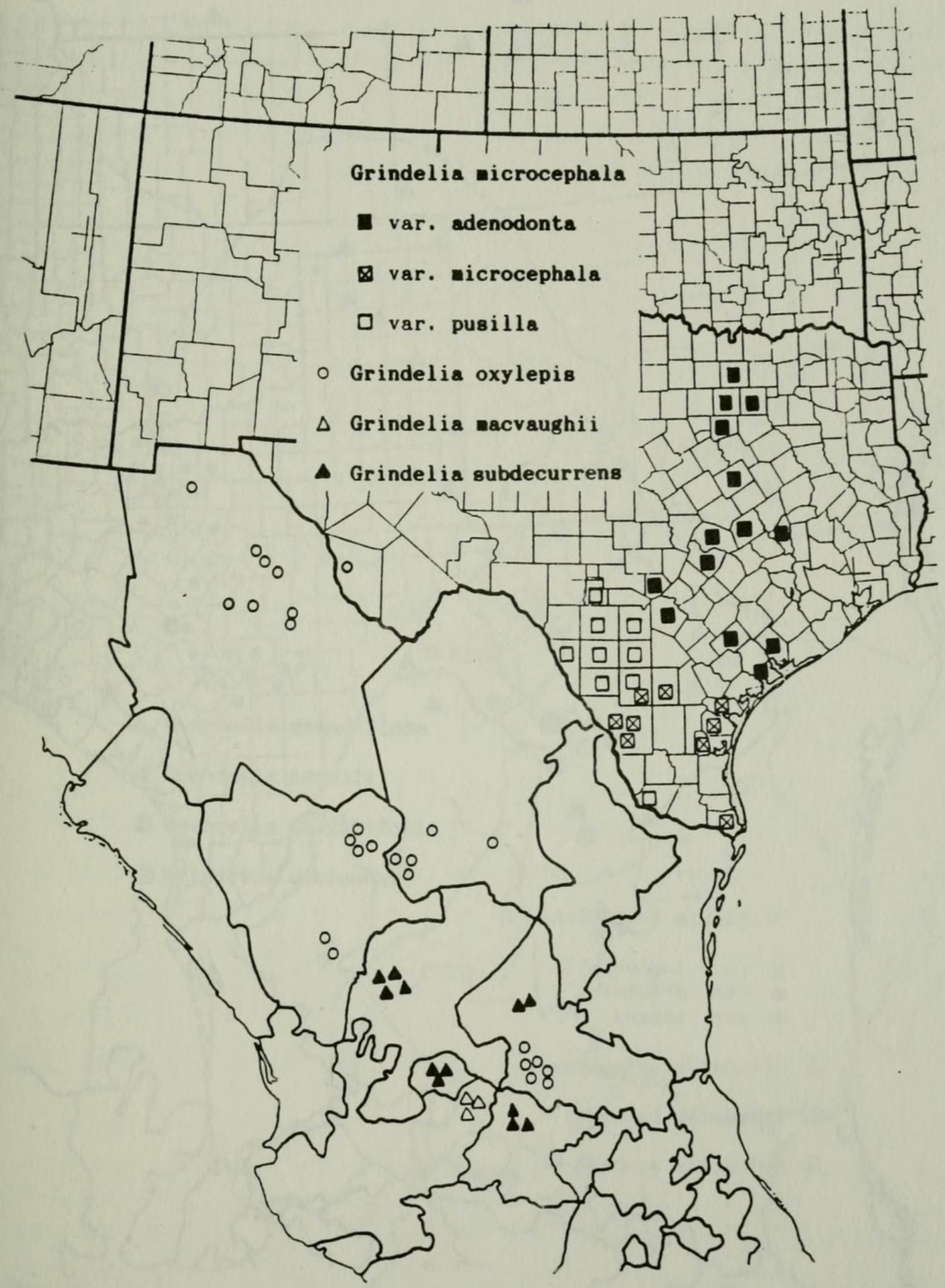

Map 2. Geographical range of Grindelia microcephala and its varieties and the radiate species of the $G$. oxylepis group. 


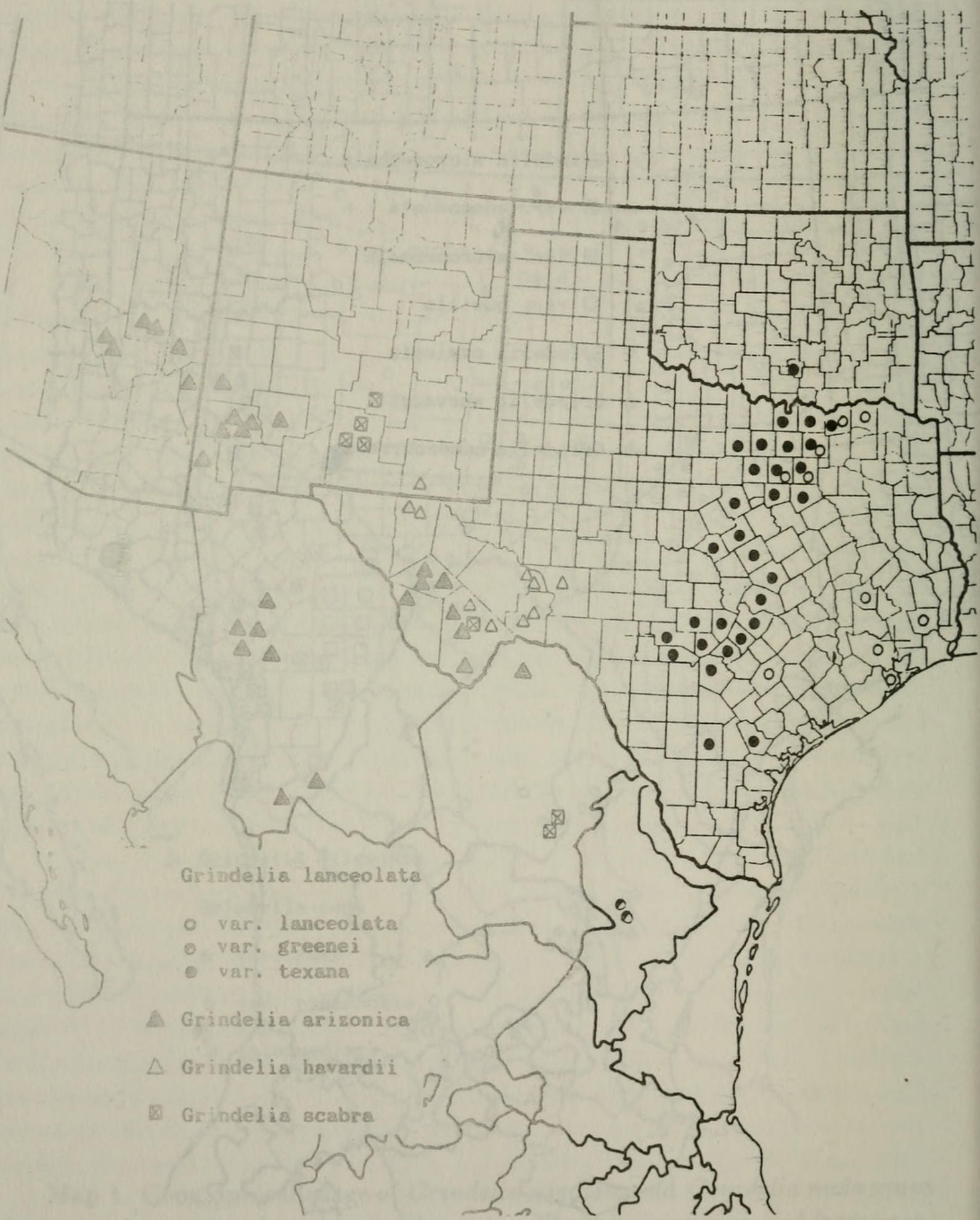

Map 3. Geographical range of Grindelia scabra, G. arizonica, G. havardii and the Texan and Mexican components of $G$. lanceolata. The range of $G$. lanceolata var. lanceolatia extends northward and eastward. The entire range of $G$. lanceolata var. texana is shown. 
Nesom:

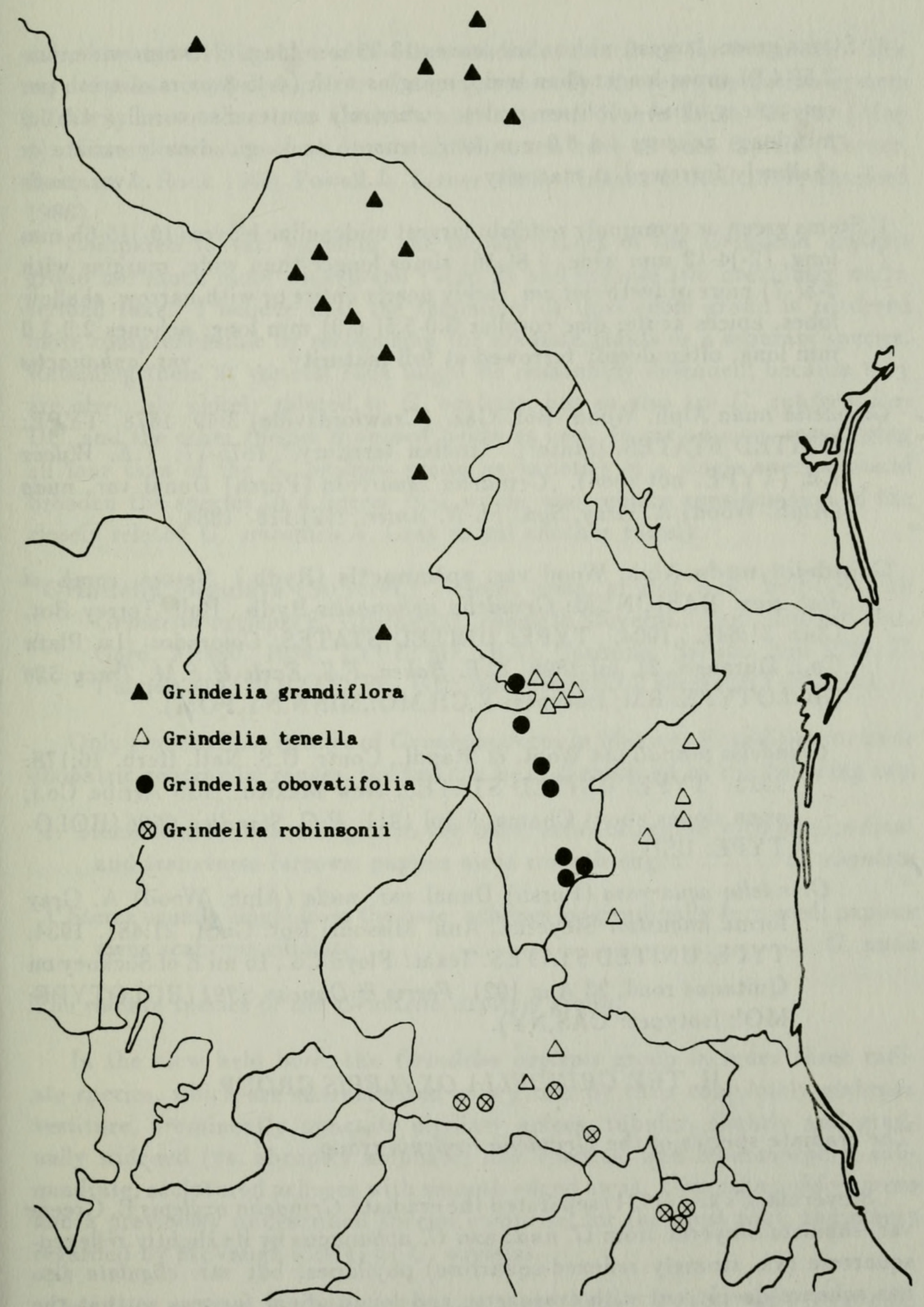

Map 4. Geographical range of the species pairs Grindelia tenella-G. grandiflora (dimorphic achenes) and G. obovatifolia-G. robinsonii (monomorphic achenes). The distributions of G. microcephala, G. scabra and G. lanceolata, which also have dimorphic achenes, are shown on Map 2 and Map 3. 
1. Stems green; largest midcauline leaves $13-35 \mathrm{~mm}$ long, 6-19 mm wide, 1.5 2.5(-4.0) times longer than wide, margins with (4-)5-8 pairs of teeth per $\mathrm{cm}$, apices blunt to obtuse or less commonly acute; disc corollas 4.5-6.0 $\mathrm{mm}$ long; achenes 1.6-3.0 mm long, smooth to longitudinally striate or shallowly furrowed at maturity $\ldots \ldots \ldots \ldots \ldots \ldots \ldots \ldots \ldots \ldots \ldots \ldots \ldots \ldots$

$1^{\prime}$ Stems green or commonly reddish; largest midcauline leaves (10-)15-65 mm long, (2-)4-13 mm wide, 4-8(-10) times longer than wide, margins with $2-5(-7)$ pairs of teeth per $\mathrm{cm}$, rarely nearly entire or with narrow, shallow lobes, apices acute; disc corollas 5.0-5.5(-6.0) mm long; achenes 2.0-3.0 $\mathrm{mm}$ long, often deeply furrowed at full maturity ....... var. aphanactis

Grindelia nuda Alph. Wood, Bot. Gaz. (Crawfordsville) 3:49. 1878. TYPE: UNITED STATES. [State?]. "Indian territory," 1875-77, T.E. Wilcox s.n. (TYPE: not seen). Grindelia squarrosa (Pursh) Dunal var. nuda (Alph. Wood) A. Gray, Syn. Fl. N. Amer. 1(2):118. 1884.

Grindelia nuda Alph. Wood var. aphanactis (Rydb.) Nesom, comb. et stat. nov. BASIONYM: Grindelia aphanactis Rydb., Bull. Torrey Bot. Club 31:647. 1904. TYPE: UNITED STATES. Colorado: [La Plata Co.], Durango, 21 Jul 1898, C.F. Baker, F.S. Earle \& S.M. Tracy 526 (HOLOTYPE: RM; Isotypes: F, GH,MO!,MINN,NY,POM).

Grindelia pinnatifida Woot. \& Standl., Contr. U.S. Natl. Herb. 16:178. 1913. TYPE: UNITED STATES. New Mexico: [Rio Arriba Co.], open slopes about Chama, 9 Jul 1911, P.C. Standley 6606 (HOLOTYPE: US!).

Grindelia squarrosa (Pursh) Dunal var. nuda (Alph. Wood) A. Gray forma angustior Steyerm., Ann. Missouri Bot. Gard. 21:481. 1934. TYPE: UNITED STATES. Texas: Floyd Co., $16 \mathrm{mi}$ E of Sockney on Quitaque road, 23 Aug 1921, Ferris \& Duncan 3391 (HOLOTYPE: MO!; Isotypes: CAS,NY).

\section{THE GRINDELIA OXYLEPIS GROUP}

The eradiate species of the Grindelia oxylepis group.

Steyermark's key (1934) separated the eradiate Grindelia oxylepis E. Greene var. eligulata Steyerm. from $G$. nuda and $G$. aphanactis by its slightly reflexedsquarrose (vs. strongly reflexed-squarrose) phyllaries, but var. cligulata also has achenes deeply cut with transverse and longitudinal furrows so that the surfaces appear pebbly (or "rugose," as they are often described). The distinctive achenes are similar to those found in typical, radiate $G$. oxylepis E. Greene, and I believe Steyermark was correct in aligning the eradiate plants 
more closely with it than with other eradiate taxa from further north. The var. eligulata comprises plants of a geographically discrete population system primarily in southeastern Coahuila and adjacent Nuevo León, México (Map 1). Numerous chromosome counts of this taxon have all been diploid (Turner, Beaman \& Rock 1960; Powell \& Turner 1963; Pinkava \& Keil 1977; Dunford 1986).

Compared to var. eligulata, the radiate plants of the Grindelia oxylepis group are much more widespread (Map 2) and include two previously undescribed taxa. I believe that the taxonomy of this whole group is rendered more comprehensible by recognizing the eradiate plants as a separate species. Retaining them at varietal rank might be reasonably defended, because they are obviously closely related to $G$. oxylepis, but so also are $G$. subdecurrens DC. and the other species proposed below as new. In my opinion, recognizing all four taxa of the $G$. oxylepis group as varieties of a single species would broaden the species to a degree that would also require consideration of the closely related $G$. arizonica A. Gray as yet another variety.

Grindelia eligulata (Steyerm.) Nesom, comb. et stat. nov. BASIONYM: Grindelia oxylepis E. Greene var. eligulata Steyerm., Ann. Missouri Bot. Gard. 21:490. 1934. TYPE: MÉXICO. Coahuila: Saltillo, Sep 1898, E. Palmer 316 (HOLOTYPE: GH; Isotypes: MO-2 sheets!,NY,UC,US).

Only two eradiate species of Grindelia occur in México. In addition to their allopatric geographic ranges, the two can be distinguished by the following key.

1. Stems usually branching from the base; achenes rugose with longitudinal and transverse furrows; pappus awns smooth edged $\ldots \ldots . G$. eligulata

$1^{\prime}$ Stems usually single from the base; achenes longitudinally furrowed; pappus awns scabrous-ciliolate ............................. nuda

The radiate species of the Grindelia oxylepis group

In the view held here, the Grindelia oxylepis group includes three radiate species, which are characterized as a group by their completely glabrous vestiture, prominently punctate phyllary apices, tubular, slightly and gradually widened (vs. abruptly ampliate) disc corollas, and monomorphic, subquadrate, sculptured achenes with smooth edged awns. Grindelia subdecurrens and a previously undescribed species comprise, for the most part, the plants regarded by McVaugh (1984) as G. oxylepis.

Grindelia oxylepis E. Greene, Pittonia 4:42. 1899. TYPE: MÉXIC'O. Chihuahua: Wet places, plains near Chihuahua, 17 Sep 1886, C.G. Pringle 748 (HOLOTYPE: US; Isotypes: GH,MICH,MINN,MO!,NY,PH,RM, $\mathrm{UC})$. 
Grindelia oxylepis E. (ireene forma capitclla Steyerm., Ann. Missouri Bot. Gard. 21:490. 1934. TYPE: MÉXICO. Durango: Mapimi, 2123 Oct 1898, E. Palmer 520 (HOLOTYPE: GH; Isotypes: MO!,NY, US). This differs from typical plants only in its smaller heads.

Grindelia oxylepis is a relatively well defined species. The primary problem with its morphological integrity is that the leaves in some populations of northern Chihuahua are spinulose tipped, intergrading with gland tipped forms. I suspect this may reflect introgression from $G$. arizonica, but field work will probably be necessary to sort this out.

Grindelia subdecurrens DC., Prodr. 5:315. 1836. TYPE: MÉXICO. Guanajuato: Villalpando, 1829, Mendez s.n. (HOLOTYPE: G-DC fiche!; Isotype: GH!).

Grindelia subdecurrens is recognized as a taprooted perennial, apparently always with several, often thin stems branching from the base. The stems and leaves are completely glabrous except for minutely scabrous leaf margins, and the leaves have punctate surfaces and blunt, glandular teeth, though usually not as strongly glandular as those in $G$. oxylepis. The achenes are smooth until the last moments of ontogeny when longitudinal furrows appear, and they produce smooth edged pappus awns. In its monomorphic, longitudinally furrowed achenes, $G$. subdecurrens is similar to $G$. arizonica although its relationship appears to lie most closely with $G$. oxylepis.

The name Grindelia subdecurrens commonly has been used as the identification for many Mexican plants, including many of $G$. inuloides Willd. s. str. Steyermark (1934) and McVaugh (1984) both have recognized G. subdecurrens as distinct, although their concepts of the species were different.

Grindelia macvaughii Nesom, sp. nov. TYPE: MÉXICO. Jalisco: $15.9 \mathrm{~km}$ E of Agua El Obispo (W of Lagos de Moreno) on Hwy 80; beside and in ditch on NW side of road, $1770 \mathrm{~m}, 20$ Aug 1979, M.E. Lane 2594 (HOLOTYPE: TEX!; Isotypes: MEXU,TEX!).

Grindclia oxylepi E. Greene similis sed duratione longiore et foliis longioribus paginis non punctatis et dentibus acutis non glandiferis differt.

Annuals or biennials, 3-9 dm tall, completely glabrous except for scabrous leaf margins. Leaves narrowly oblong to oblanceolate or lanceolate, clasping, not decurrent, $2.0-3.5 \mathrm{~cm}$ long at midstem, $4-7 \mathrm{~mm}$ wide, reduced near the heads, not punctate, with $9-15$ pairs of strongly spinulose or sharp indurated, eglandular teeth. Heads $12-17 \mathrm{~mm}$ wide, on short peduncles; phyllaries strongly graduated in length, the inner $7.9 \mathrm{~mm}$ long, white indurated 
except at the very tip, the outer with loose, erect to spreading or reflexing, herbaceous punctate apices. Ray flowers 15-20. Disc corollas 5-6 mm long, not sharply ampliate. Achenes $2.5-3.5 \mathrm{~mm}$ long, subquadrate, with prominent transverse incisions and broad, shallow, longitudinal furrows; pappus awns smooth, nearly as long as the disc corollas.

Endemic to northeast Jalisco in the area around Lagos de Moreno; clay soil, ditches, grasslands, pastures, with desert shrubs, including Acacia and Artemisia; 1800-1900 m; Aug-Oct.

Additional collections examined: MÉXICO. Jalisco: about $11 \mathrm{mi} \mathrm{SE}$ of Lagos de Moreno, near hwy to León, $1900 \mathrm{~m}, 7 \mathrm{Sep}$ 1952, McVaugh 12820 (F,SMU); 11 mi SE of Lagos de Moreno, 16 Aug 1957, Waterfall 13869 (SMU).

Grindelia macvaughii differs from $G$. oxylepis primarily in its longer leaves with nonpunctate surfaces and sharp, eglandular teeth. The three radiate species of the Grindelia oxylepis complex can be distinguished by the following key.

1. Annuals, usually single stemmed from the base; leaves mostly $8-15(-25)$ $\mathrm{mm}$ long, $3-5 \mathrm{~mm}$ wide, $2.0-2.5(-5)$ times longer than wide; achenes deeply sculptured at early maturity $\ldots \ldots \ldots \ldots \ldots \ldots \ldots$. oxylepis

$1^{\prime}$ Annuals, biennials or short lived perennials, with several stems from the base; leaves mostly $15-40 \mathrm{~mm}$ long, 3-8 $\mathrm{mm}$ wide, 4-7 times longer than wide; achenes smooth or sculptured at early maturity

2. Perennials; leaf surfaces punctate; foliar teeth mostly glandular; ray flowers 20-30; achenes smooth at early maturity, developing longitudinal furrows at late maturity .......... subdecurrens

2 ' Annuals or biennials; leaf surfaces nonpunctate; foliar teeth definitely spinulose, not at all glandular; ray flowers $15-20$; achenes usually prominently sculptured even at early maturity, with prominent transverse incisions and longitudinal furrows . G. macvaughii

A new species peripherally related to Grindelia oxylepis.

Grindelia turneri Nesom, sp. nov. TYPE: MÉXICO. Nuevo León: Mpio. Galeana, between San Pablo and Tanquecillos, $0.5 \mathrm{mi} \mathrm{S}$ of San Pablo, on the road between San Rafael Jct and Galeana, fallow fields in valley, pines on high slopes of valley margins, $2320 \mathrm{~m}, 27$ Aug 1989, G. Nesom 7189 with J. Norris (HOLOTYPE: TEX; Isotypes: ANSM,COLO,ENCB,F, GH,KANU,MEXU,MO,NY,RM,US,WAT,WIS).

Grindelia oxylepi Greene similis sed duratione perenni, ramificatione basali, paginis foliorum minute puberulis non-punctatis, et aristis pappi quam corollis discii longioribus differt. 
Perennials from thick, woody taproots, with numerous, basally decumbentascending branches arising from the crown. Stems $13-33 \mathrm{~cm}$ tall, glabrous or with a few, minute hairs. Basal leaves usually not persistent, lower to midcauline with blunt, gland tipped teeth, not punctate, glabrous, sometimes minutely scabrous near the margins or commonly with scattered puberulous hairs, clasping, oblong to oblong-lanceolate, mostly $15-45 \mathrm{~mm}$ long, 4-9 $\mathrm{mm}$ wide, slightly reduced in size upwards. Heads $14-20 \mathrm{~mm}$ wide, solitary on leafy peduncles; phyllaries lanceolate, subequal in length, the inner 3-4 series erect, 7-10 mm long, the outer spreading but not reflexed, whitish indurated on the basal $1 / 2-2 / 3$, the apex herbaceous punctate; receptacles alveolate. Ray flowers $18-28$, the corollas $12-18 \mathrm{~mm}$ long. Disc corollas $4.8-5.2 \mathrm{~mm}$ long, abruptly ampliate above the tube. Achenes 2.1-3.0 mm long, monomorphic, slightly flattened to 3 angled, smooth or with short, shallow, transverse incisions at late maturity; pappus awns 2, smooth edged, 1-2 mm longer than the disc corollas.

Endemic to Nuevo León in an area NNW of Galeana; valley bottoms in deep soil and surrounding, rocky, gypsum-limestone hillsides, areas of desert scrub to pine or pine-yucca woods; 1900-2550 m; (May-)August-October(November).

Additional collections examined: MÉXICO. Nuevo León: Mpio. Galeana: road to 18 de Marzo, $8.7 \mathrm{mi}$ E of jct with Hwy 57 [at San Rafael], 5 Aug 1983, Freeman \&6 Wetter 2056 (TEX,WIS-2 sheets); $8 \mathrm{mi}$ E of San Rafael on road to 18 de Marzo, $4.4 \mathrm{mi}$ E of La Boca, 22 Oct 1982, Grimes 2278 (TEX); Tanquecillos, 11 May 1980, Hinton, et al. 17760 (TEX); E of San Rafael, $5.6 \mathrm{mi}$ ESE of San Pablo, 30 Nov 1986, Nesom 5281 (MEXU,TEX); ca 2 mi W of San Pablo, overlooking the town, open, grassy slopes at edge of pine woods, 2300 m, 27 Aug 1989, Nesom 7184 (ANSM,KANU,MEXU,MO,NY,RM,TEX,WIS); ca $2 \mathrm{mi} \mathrm{S}$ of Tanquecillos on road toward Galeana, open, sloping area of shaly limestone with scattered pines, $2450 \mathrm{~m}, 27$ Aug 1989, Nesom 7192 (MEXU,TEX); $20.6 \mathrm{mi} \mathrm{N}$ of San Roberto Jct on Hwy 57, 12 Oct 1984, Sundberg 3131 (TEX,WIS).

Most of the collections of Grindelia turneri have been made within and on the low sides of the large valley that situates the towns of San Pablo and Tanquecillos, Nuevo León (Map 6). One collection (Sundberg 3131) is from the north edge of the large gypseous valley of Entronque San Rafael and San Roberto. The species is named for Dr. B.L. Turner, whose study of the systematics of Mexican ('ompositae within nearly all tribes has been of great influence.

The perennial duration and "bowl-shaped" habit of Grindelia turneri are similar to those of the northern plants of $G$. inuloides, which occurs on mountainsides overlooking the valley of San Pablo to the south. The glabrous stems, punctate phyllary apices, and wrinkled achenes, however, are features more similar to $G$. oxylcpis E. Greene. In contrast to $G$. oxylepis, the leaves 
of G. turneri are not punctate and often produce minute, eglandular hairs or glands (vs. punctate and completely glabrous in G. oxylepis). Further, plants of $G$. oxylepis are annual, usually with strictly erect stems that arise singly from the base. Grindelia turneri is distinctive among Mexican species in its pappus awns that extend $1-2 \mathrm{~mm}$ above the disc corollas.

\section{GRINDELIA NELSONII}

Grindelia nelsonii Steyerm. is restricted to southeastern Jalisco and immediately adjacent Michoacán and Colima (Map 5). The plants are characterized by tall stems $(0.4-2.0 \mathrm{~m})$ and are distinctive in bearing numerous heads in corymbs. The leaves are nearly glabrous with gland tipped teeth and have bases decurrent for $2-5(-10) \mathrm{mm}$. The outer phyllaries are long and very narrow. These plants were identified by McVaugh (1984) as G. subdecurrens, to which they appear to be closely related, although the relationship may be as close to G. oxylepis.

The type collection of Grindelia nelsonii (Isotype: GH!) was made at the eastern edge of the range of the species (Map 5) and appears to be aberrant in several significant respects. The cauline leaves are barely to not at all decurrent, and while the upper leaves have gland tipped teeth, the teeth of the lower ones are sharp pointed and subspinulose. In these features the plants are more like $G$. inuloides. In contrast, the glabrate leaves, gland tipped teeth and corymbose capitulescence are distinctive, and firmly align the type collection with the population system of similar plants to the west. Even if genes of $G$. inuloides were represented through hybridization or introgression in the type collection, the basis of the identity of $G$. nelsonii is firmly enough established through the type.

The only other species of Grindelia that occurs within the range of $G$. nelsonii is G. sublanuginosa Steyerm., which is a distinctive species but known only from a few collections around the northern and southern margins of Lake Chapala (Map 5). Plants of G. sublanuginosa have densely villous and stipitate glandular stems, solitary heads, and deeply sculptured achenes.

\section{THE GRINDELIA ARIZONICA COMPLEX}

In this treatment, Grindelia arizonica A. Gray is viewed as a species that comprises three apparently disjunct population systems and that extends from southeastern Arizona through southwestern New Mexico, trans-Pecos Texas, and into Chihuahua and Coahuila, México (Map 3). It is distinguished by its glabrous, often reddish stems, glabrous leaves (except for the scabrous margins) with spinulose teeth, monomorphic achenes with longitudinal furrows at maturity, and pappus awns with ciliolate-scabrous margins. It is closely related to $G$. oxylepis, with which it shares strongly punctate phyllary apices and monomorphic achenes. Grindelia havardii Steyerm. also is closely similar 


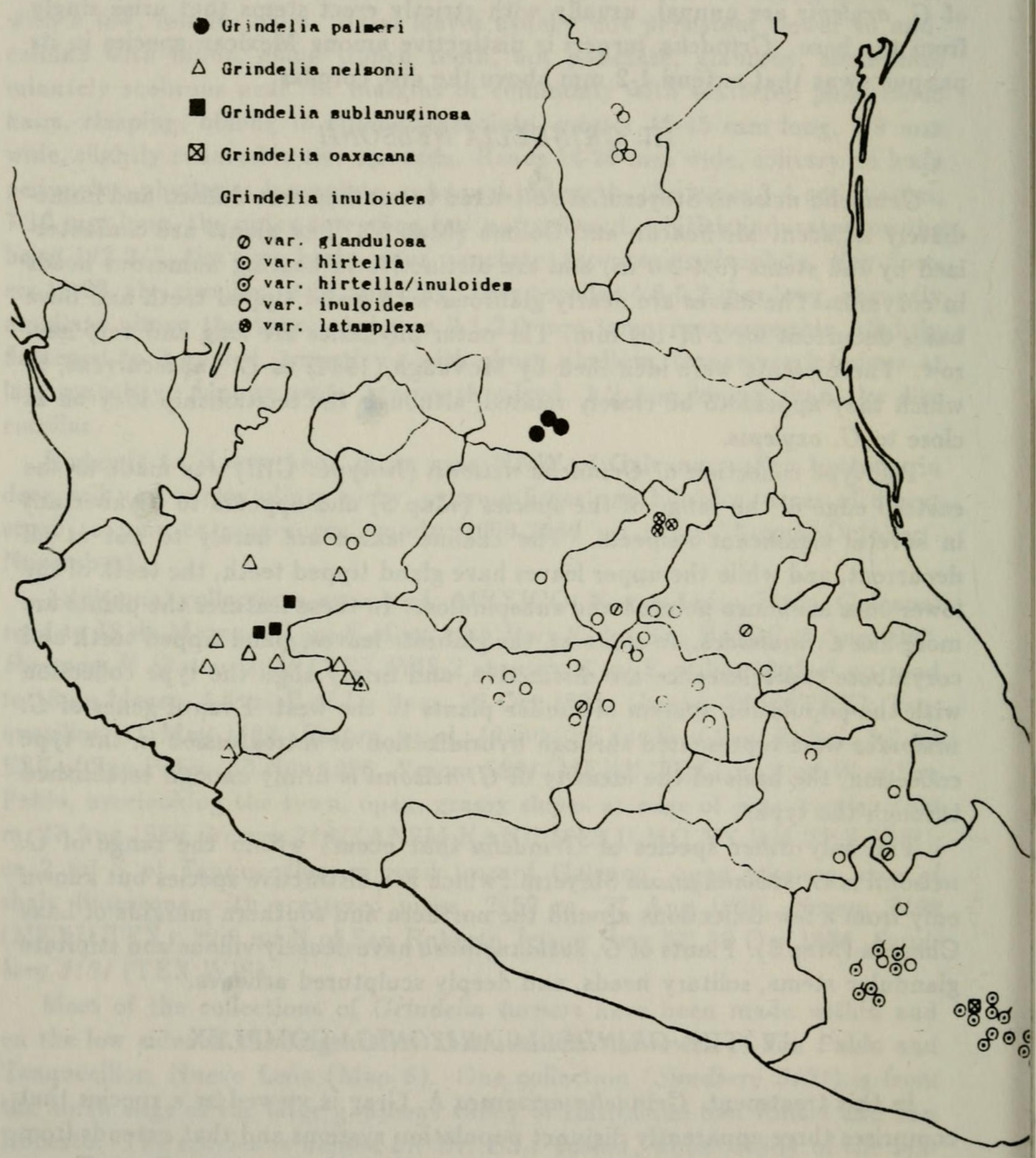

Map 5. Geographical range of Grindelia inuloides, G. oaxacana, G. palmeri, $G$. nelsonii and $G$. sublanuginosa. The type locality of $G$. nelsonii is shown by an open triangle enclosing a dot. 
Nesom:

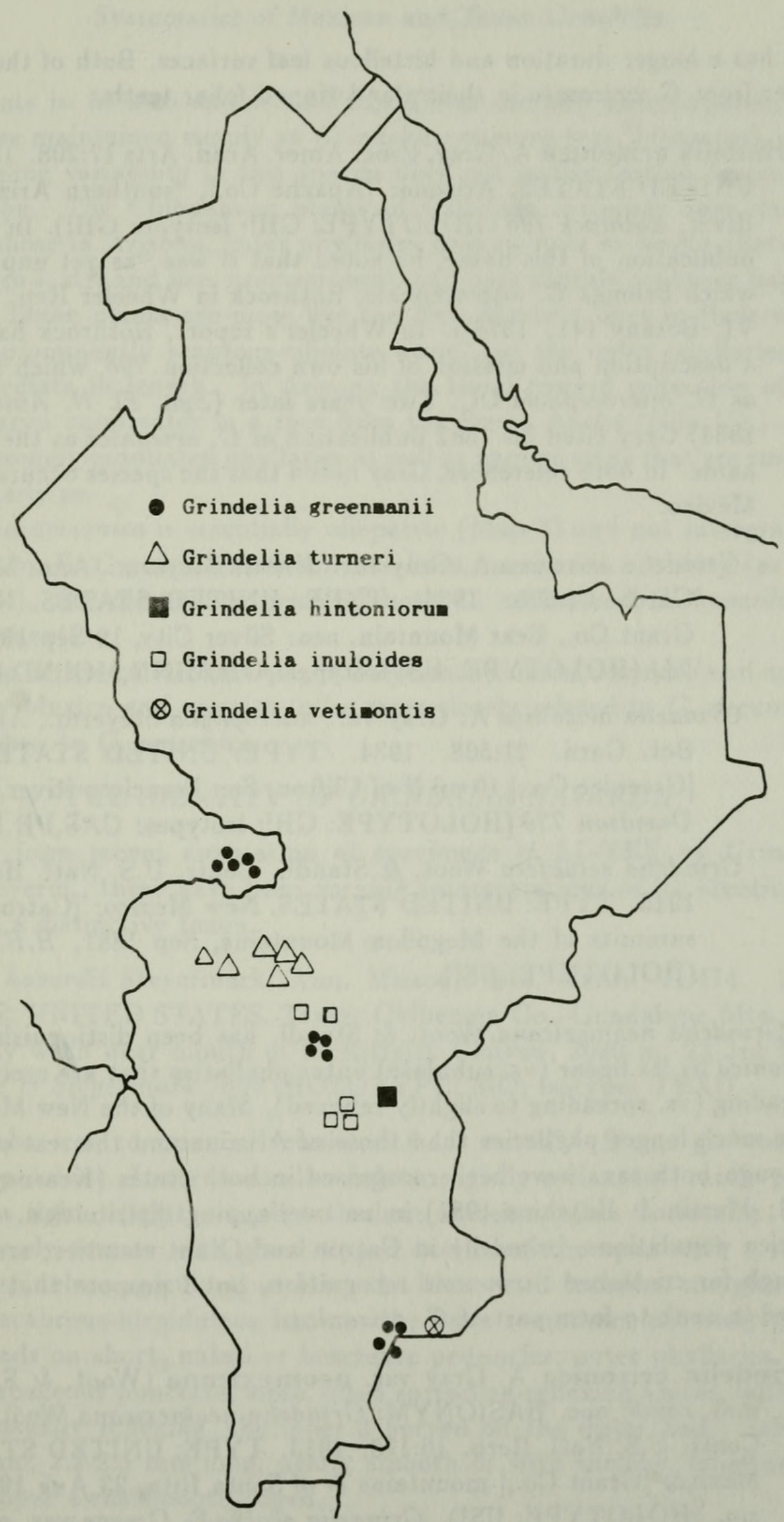

Map 6. Geographical range of Grindelia vetimontis, G. turneri, G. hintoniorum, G. greenmanii and G. inuloides in Nuevo León, Coahuila and Tamaulipas. 
but has a longer duration and hirtellous leaf surfaces. Both of the latter differ from $G$. arizonica in their gland tipped foliar teeth.

Grindelia arizonica A. Gray, Proc. Amer. Acad. Arts 17:208. 1882. TYPE: UNITED STATES. Arizona: [Apache Co.], "southern Arizona," Black River, Rothrock 796 (HOLOTYPE: GH!; Isotype: GH!). In Gray's 1882 publication of this name, he noted that it was "as yet unpublished (to which belongs G. microcephala, Rothrock in Wheeler Rep. 141)" ([Vol. VI.-Botany 141. 1878]). In Wheeler's report, Rothrock had presented a description and citation of his own collection 796, which he identified as G. microcephala DC. Two years later (Syn. Fl. N. Amer. 1[2]:118. 1884) Gray cited his 1882 publication of $G$. arizonica as the origin of its name. In both references, Gray noted that the species occurs in northern México.

Grindelia arizonica A. Gray var. dentata Steyerm., Ann. Missouri Bot. Gard. 21:508. 1934. TYPE: UNITED STATES. New Mexico: Grant Co., Bear Mountain, near Silver City, 19 Sep 1903, Metcalfe 744 (HOLOTYPE: US; Isotypes: GH,MINN,MO!,ND,NY,RM).

Grindelia arizonica A. Gray var. microphylla Steyerm., Ann. Missouri Bot. Gard. 21:508. 1934. TYPE: UNITED STATES. Arizona: [Greenlee Co.,] $10 \mathrm{mi}$ N of Clifton, San Francisco River, 7 Sep 1902, Davidson 736 (HOLOTYPE: GH!; Isotypes: CAS,PH,RM).

Grindelia setulifera Woot. \& Standl., Contr. U.S. Natl. Herb. 16:179. 1913. TYPE: UNITED STATES. New Mexico: [Catron Co.,] high summits of the Mogollon Mountains, Sep 1881, H.H. Rusby 206 (HOLO'TYPE: US!).

Grindelia neomexicana Woot. \& Standl. has been distinguished from $G$. arizonica by its linear (vs. subulate) outer phyllaries that are erect to slightly spreading (vs. spreading to slightly reflexed). Many of the New Mexico plants have much longer phyllaries than those of Arizona and the rest of the range, although both taxa have been recognized in both states (Kearney \& Peebles 1951; Martin \& Hutchins 1981) in an overlapping distribution. These New Mexico populations, primarily in Catron and Grant counties, are distinctive enough for continued taxonomic recognition, but I propose that they be reduced in rank to form part of $G$. arizonica.

Grindelia arizonica A. Gray var. neomexicana (Woot. \& Standl.) Nesom, comb. nov. BASIONYM: Grindelia neomexicana Woot. \& Standl., Contr. U.S. Natl. Herb. 16:178. 1913. TYPE: UNITED STATES. New Mexico: [Grant Co.,] mountains N of Santa Rita, 23 Aug 1900, Wooton s.n. (HOLOTYPE: US!). Grindelia scabra E. Greene var. neomexicana (Woot. \& Standl.) Steyerm., Ann. Missouri Bot. Gard. 21:510. 1934. 
The plants in México and trans-Pecos Texas are also differentiated, but they are here maintained simply as Grindelia arizonica (var. arizonica), since the overlapping variability in this species does not justify further taxonomic fragmentation. The Chihuahuan plants of Grindelia arizonica have narrow leaves like those in Arizona, outer phyllaries intermediate in length (between var. arizonica s. str. and var. neomexicana), and only slightly scabrous pappus awns. The Texan plants are more like the New Mexican ones in their wider leaves and prominently scabrous-ciliolate awns, but the outer phyllaries are also intermediate in length. In Arizona the trend toward reduction of the outer phyllaries culminates in a race from the Sierra Ancha (Gila Co.) that have very strongly graduated phyllaries as well as pappus awns that are smooth edged or nearly so.

Grindelia arizonica is essentially allopatric (Map 3) and not intergrading with G. scabra E. Greene, of which it has been considered a variety (as var. neomexicana). See discussions below of both G. scabra and G. havardii for further comments.

Grindelia arizonica var. stenophylla Steyerm. occurs in Colorado and northeastern New Mexico and appears to be more closely related to $G$. decumbens E. Greene than to $G$. arizonica.

\section{THE IDENTITY OF GRINDELIA HAVARDII}

Judging from recent annotation of specimens in LL-TEX as Grindelia havardii Steyerm., there have been varying interpretations of its identity. It is, however, a distinctive taxon.

Grindelia havardii Steyermark, Ann. Missouri Bot. Gard. 21:474. 1934. TYPE: UNITED STATES. Texas: Culberson Co., Guadalupe Mts., dry, gravely wash near mouth of McKittrick Canyon, 2000 m, 23 Jul 1931, Moore \& Steyermark 3607 (HOLOTYPE: MO; Isotype: TEX!).

Perennials, less commonly biennial, $0.6-1.5 \mathrm{~m}$ tall. Stems glabrous or sparsely hispidulous. Leaves ovate-lanceolate, slightly coriaceous, rarely punctate, with a tight, slightly raised reticulum of veins, often noticeably $3(-5)$ veined, coarsely serrate with gland tipped teeth but the apex with a short, indurated, spinulose apiculum, at least the lower with scabrous margins and often with scabrous-hispidulous lamina, the hairs sometimes minutely gland tipped. Heads on short, naked or bracteate peduncles; outer phyllaries with teretish, herbaceous punctate, loose, often spreading-reflexing apices, with the outermost usually reflexing, the inner 3 nerved on the distal half. Achenes monomorphic, 2.2-2.5 mm long, nearly smooth or with shallow, longitudinal furrows; pappus awns smooth edged.

Trans-Pecos Texas and Eddy Co., New Mexico; open sites, rocky slopes of limestone, less commonly alluvium; ca 1300-2000 m; June-September (-October). 
Grindelia havardii has been considered to be similar and closely related to G. lanceolata Nutt. Grindelia lanceolata, however, always has spinulose foliar teeth and dimorphic achenes and it is geographically distant from $G$. havardii. The latter has blunt, gland tipped foliar teeth, monomorphic achenes, and is endemic to trans-Pecos Texas and adjacent New Mexico. The achenes of $G$. havardii are similar to those of $G$. arizonica, and in view of their putative hybridization, discussed below, I believe these two species probably are closely related.

The geographic range of Grindelia arizonica, which has spinulose foliar teeth, linear, erect phyllaries, and scabrous-ciliolate pappus awns, is more or less contiguous with that of $G$. havardii in Jeff Davis and Brewster counties (Map 3), although it appears to be more or less restricted to the igneous substrates to the southwest of the limestone area typical of $G$. havardii. Where their ranges abut, apparent intermediates occur between the two. Even there, however, the foliar teeth tend to be either mostly spinulose or glandular and the pappus awns smooth or ciliolate, and I have separated the two taxa on that basis. The foliar teeth of some of these putative intermediates are glandular on the proximal portion of the margins and sharp spinulose above.

The most strongly perennial forms of Grindelia havardii occur in Culberson Co., Texas. In the eastern part of the range, plants have more slender taproots, longer, more reflexing phyllaries and plants of one collection from Terrell Co. (Raven \& Gregory 19196, SMU) have glandular but also slightly spinulose teeth.

\section{THE IDENTITY OF GRINDELIA SCABRA}

Grindelia scabra E. Greene, Bull. Torrey Bot. Club 25:120. 1898. LECTOTYPE (designated here): UNITED STATES. New Mexico: Otero Co., White Mts., $6300 \mathrm{ft}, 21 \mathrm{Aug}$ 1897, E.O. Wooton 224 (US!). Greene also cited Wooton 372 (US).

Annual or biennial, from a taproot distinctly thickened at the stem/root junction. Stems sparsely to densely villous, eglandular. Leaves oblong to oblong-lanceolate with a rounded to slightly cordate hase, clasping, sessile or on a short stipitate petiole, the margins serrate with $10-15$ pairs of short spinulose teeth, the lamina sparsely hispidulous-pilose with short hairs, nonpunctate, eglandular or the Texas plants with minute, sessile resin glands. Heads $16-20 \mathrm{~mm}$ wide, immediately subtended by leaf like bracts; phyllaries glabrous, lanceolate-triangular, erect or the outer spreading, the innermost $10-11 \mathrm{~mm}$ long, all except the inner with a spinulose apex, with 3-5 longitudinal veins often prominent on at least the distal half. Achenes apparently somewhat dimorphic, the outer mostly smooth and 3 angled, the inner compressed, with slightly raised, longitudinal nerves; pappus awns minutely ciliolate-scabrous. 
Because this species has not been previously recorded from Texas or México, the following specimens are cited.

UNITED STATES. Texas: Brewster Co., Gage Estate, Del Norte Mts., infrequent in deep limestone canyon on east side of Mt. Ord, $5000 \mathrm{ft}, 14 \mathrm{Jul}$ 1947, Warnock 6466 (SMU).

MÉXICO. Coahuila: Monclova, [Sierra de Gloria,] 20 Jul 1939, Marsh 1845 (F,TEX); Monclova, [Sierra de Gloria,] 3 Aug 1939, Marsh 1883 (F,TEX).

Grindelia scabra is similar to G. microcephala DC. of Texas in its leafy bracteate heads and villous stems. It does not appear to be more closely related to $G$. arizonica, which has been treated as a variety (as G. scabra var. neomexicana, see discussion of $G$. arizonica above), than to $G$. microcephala. Grindelia microcephala differs from G. scabra in its blunt, gland tipped foliar teeth, smaller heads, enervate inner phyllaries and smooth edged pappus awns. Grindelia arizonica differs in its glabrous stems and leaves, heads without large, subtending, foliar bracts and monomorphic achenes with longitudinal furrows.

The leaves of the Mexican plants of Grindelia scabra are slightly stipitate on petioles 1-2 mm long. While this appears to be an unusual feature, it can also be seen, though rarely, in related species, where a decurrent leaf base appears to be slightly separated from the stem. Although the plants of the Mexican collections lack roots and mature achenes, they appear best placed in this species, at least until further collections can be made. The lectotype has narrowly linear outer phyllaries but otherwise is typical for the species.

\section{VARIATION IN GRINDELIA MICROCEPHALA}

As presented here, Grindelia microcephala comprises three distinct population systems, each recognized as a separate variety. The plants are annuals with sparsely to moderately but closely villous stems. The leaves have blunt, gland tipped teeth and the heads are small (8-12 mm wide), immediately subtended by relatively unreduced cauline leaves. The phyllaries are enervate, with green, nonpunctate, spreading-erect apices. The achenes are dimorphic, with morphology variable among the varieties and producing smooth edged pappus awns.

Grindelia microcephala apparently is endemic to Texas. Althongh it has been collected very near the Mexican border at several localities (Map 2), no stations from México are known. Three remarkably distinct varieties occur, each occupying a relatively restricted geographic range, almost completely allopatric with the other varieties. Although heads with mature fruits are required to distinguish them with certainty, there appear to be but few collections that might be identified as intermediates.

1. Leaves often with conspicuous sessile or stipitate resin glands, sometimes punctate-resinous; outer achenes deeply and sharply cut with transverse 
furrows, the inner abortive or fertile, flat and many nerved; southwest Edwards Plateau; March-May ......................... pusilla

$1^{\prime}$ Leaves usually punctate-resinous, rarely with sessile or minutely stipitate and inconspicuous resin glands; outer achenes smooth, longitudinally furrowed, or slightly roughened rugose, the inner achenes abortive and undeveloped or fertile, flat, and many nerved

2. Outer achenes roughened rugose, not at all transversely incised, at least some of the inner achenes fertile, strongly flattened and as long as or longer than the outer, with numerous, whitish, longitudinal nerves; Blackland Prairie region of Texas; June-

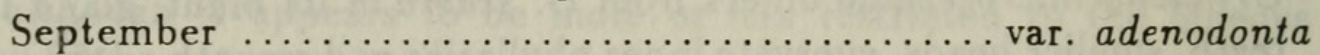

$2^{\prime}$ Outer achenes smooth, plump and rounded, to 3 sided with a few, rounded, longitudinal furrows, commonly with short, shallow, transverse incisions, the inner achenes completely abortive; Rio Grande plains; (November-)March-June(-August) .......var. microcephala

Grindelia microcephala DC. var. microcephala.

Grindelia microcephala DC. var. microcephala. Grindelia microcephala DC., Prodr. 5:315. 1836. TYPE: UNITED STATES. Texas: 1832, Berlandier 2057 (HOLOTYPE: G-DC, fiche!; Isotypes: GH,MO!,NY). Grindelia inuloides Willd. var. microcephala (DC.) A. Gray, Syn. Fl. N. Amer. 1(2):117. 1884 .

Steyermark (1934: p. 467) cited "Berlandier 647 (2057)" as the type of Grindelia microcephala (Texas, "in campis prope Rio Frio, Juli 1829 and Juli 1829" -.. (iH the holotype, with isotypes MO,NY). The smaller number (647) is a "distribution number" by Berlandier for the larger one (2057). The collection data in DeCandolle's description, in contrast, cited only Texas, without specific locality, 1832, Berlandier 2057. Because there is a specimen in G-DC (fiche!) that exactly matches DeCandolle's published data, it must be assumed to be the holotype. Further, DeCandolle's notes on this specimen leave little doubt regarding its identity: "Flores disci steriles in specim. meo videntur. Achaenia radii matura grossa calva." Thus, the collection almost certainly must have been made from lower parts of the Frio River in McMullen County, where plants with such features occur and through which Berlandier passed in his travels (Muller \& Muller 1980).

Variety microcephala appears to be most closely related to var. pusilla, as evidenced by its abortive inner ovaries, the slight transverse incisions on the mature achenes and its flowering that begins in early spring. 
Grindelia microcephala DC. var. pusilla Steyerm.

Grindelia microcephala DC. var. pusilla Steyerm., Ann. Missouri Bot. Gard. 21:467. 1934. TYPE: UNITED STATES. Texas: [Frio or LaSalle Co.,] between the Frio and Nueces Rivers, on the road to Laredo, 27-28 Jan 1880, E. Palmer 469 (HOLOTYPE: GH; Isotypes: MO!,NY,US).

Grindelia microcephala DC. var. adenodonta Steyerm. forma angustior Steyerm., Ann. Missouri Bot. Gard. 21:469. 1934. TYPE: UNITED STATES. Texas: Uvalde Co., near Uvalde, rocky, open ground along small stream, 28 Apr 1928, E.J. Palmer 33590 (HOLOTYPE: MO!; Isotypes: LL!,NY).

Grindelia microcephala DC. var. adenodonta Steyerm.

Grindelia microcephala DC. var. adenodonta Steyerm., Ann. Missouri Bot. Gard. 21:467. 1934. TYPE: UNITED STATES. Texas: [Fayette Co.,] $39 \mathrm{mi} \mathrm{W}$ of San Felipe, Jul-Aug 1844, Lindheimer 255 (HOLOTYPE: MO!; Isotypes: $\mathrm{GH}, \mathrm{PH}, \mathrm{UC}$ ).

The status of Grindelia microcephala D.C. var. montana Steyerm.

The collection described by Steyermark as Grindelia microcephala var. montana is similar to $G$. microcephala in its heads immediately subtended by relatively unreduced cauline leaves. In contrast, besides its extremely wide geographic disjunction and different habitat, the Oaxacan taxon differs from G. microcephala in its much taller and densely stipitate glandular stems, nonglandular foliar teeth, and strongly 3-5 nerved phyllaries. It appears to be a distinct species and is here formally elevated in rank.

Grindelia oaxacana Nesom, nom. nov. Based on: Grindelia microcephala DC. var. montana Steyerm., Ann. Missouri Bot. Gard. 21:470. 1934; non Grindelia montana Phil., 1894. TYPE: MÉXICO. Oaxaca: Mts. San Juan del Estado, 7500 ft, 13 Aug 1894, L.C. Smith 135 (HOLOTYPE: GH!).

Plants at least $40 \mathrm{~cm}$ tall, apparently much taller, duration unknown. Stems densely stipitate glandular, the glands orange resinous, mixed with nonglandular, villous hairs. Leaves oblong-ovate, $2-5 \mathrm{~cm}$ long, $8-20 \mathrm{~mm}$ wide, mostly even sized upwards, the surfaces minutely glandular, the teeth blunt, neither glandular nor spinulose. Heads $16-22 \mathrm{~mm}$ wide, immediately subtended by cauline leaves little reduced in size; phyllaries glabrous to slightly sessile glandular, oblong-obovate, abruptly narrowed to a strongly reflexed apex, the middle $2.5-2.8 \mathrm{~mm}$ wide, 5 nerved. Rays $16-22,14-16 \mathrm{~mm}$ long. Disc corollas $5 \mathrm{~mm}$ long. Mature achenes not observed; pappus awns smooth edged. 
Known only from the type collection.

This species is distinctive in its large leaves and heads immediately subtended by relatively unreduced cauline leaves. Grindelia sublanuginosa Steyerm., from Jalisco, is similar in some respects, but $G$. oaxacana differs by its taller stems that are much more densely stipitate glandular and not densely villous, leaves larger and relatively broader, and phyllaries strongly nerved, the outer abruptly narrowed to a reflexing apex. Populations of Grindelia inuloides, the only other species of Grindelia in Oaxaca, also occur in the central part of the state, but are much more common than $G$. oaxacana (Map 5 ). The latter has stems taller, villous and eglandular to very slightly and minutely glandular, leaves smaller with the upper strongly reduced and phyllaries enervate or barely nervate.

\section{VIII. 'THE STA'TUS OF GRINDELIA GREENEI}

The Mexican taxon Grindelia greenei is best treated as a variety of $G$. lanceolata Nutt.

Grindelia lanceolata Nutt. var. greenei (Steyerm.) Nesom, comb. et stat. nov. Grindelia grecnei Steyerm., Ann. Missouri Bot. Gard. 21:517. 1934. TYPE: MÉXICO. Nuevo León: vicinity of Monterrey, 1924, C.R. Orcutt 1204 (HOLOTYPE: US!).

Additional collections examined: MÉXICO. Nuevo León. Monterrey, "foot Chipi[n]que," 9 Oct 1937, Kenoyer 300 (F,MO); Monterrey, 1924, Orcutt 1249 (US).

The plants of the type collection of Grindelia greenei apparently were far disjunct from the main range of $G$. lanceolata (Map 3). Only the type collection and two others of this taxon, both from Monterrey or its vicinity, are known from México, and the current urban expansion of that city makes it improbable that the original population has survived. The broadly ovate-elliptic leaves of the Mexican plants, consistently among the collections examined, are different from those of both var. lanceolata and var. texana (Scheele) Shinners, and they have somewhat smaller, more regular teeth. The phyllaries are only weakly graduated to subequal in length, most like those of var. lanceolata. In their perennial duration, glabrous vestiture, punctate leaves with stoutly spinulose teeth and dimorphic achenes, the plants of $G$. greenei clearly belong with $G$. lanceolata.

Perhaps the largest amount of variability in Grindelia lanceolata occurs in the extreme southern portion of its range. Steyermark (1934: p. 517) described $G$. littoralis Steyerm. as an "endemic of the Galveston Bay region ...intermediate between $G$. lanceolata and $G$. texana" with more closely appressed and incurved foliar teeth and with pappus awns with "several projections" rather than "entire or subentire." With many more collections from 
around Galveston now at hand, however, I agree with Johnston (1970) that $G$. littoralis cannot be separated from $G$. lanceolata.

\section{THE GRINDELIA INULOIDES S. STR. COMPLEX}

As noted below, Grindelia inuloides Willd. is an extremely variable species. It is recognized by its taprooted habit, nonpunctate leaves with sharp pointed, nonglandular teeth (glandular in one variety), stem pubescence at least sparsely villous, heads mostly solitary, phyllaries variable in morphology but never with punctate apices and monomorphic achenes with smooth or weakly sculptured surfaces.

\section{Grindelia inuloides Willd.}

Annuals, biennials, or perennials from taproots, most commonly single stemmed from the base but often with several ascending branches from the crown. Stems $2-7(-10)$ dm tall, very sparsely villous to glabrate, eglandular or sometimes glandular. Lower and midcauline leaves oblong-obovate to oblonglanceolate or lanceolate, 25-50 mm long, 3-10 mm wide, 5-9 times longer than wide, clasping, decurrent $0(-3) \mathrm{mm}$, reduced in size upwards and becoming triangular-lanceolate to linear, minutely and sparsely appressed puberulent, not punctate. Heads 12-20 mm wide, solitary; phyllaries 8-11 mm long, equal to subequal or strongly graduated in length, sparsely puberulous to glabrate, not punctate or nervate, the lower portion usually strongly white indurated. Ray flowers 23-50, the corollas $12-18 \mathrm{~mm}$ long. Disc corollas 4.0-5.0 mm long, abruptly ampliate above the tube. Achenes monomorphic, slightly flattened to 3 angled, smooth or with distinct transverse incisions near the top; pappus awns 2-5(-6), smooth edged.

\section{KEY TO THE VARIETIES}

1. At least the upper stems, leaves, and phyllaries densely and prominently stipitate glandular

$1^{\prime}$ Stems and phyllaries eglandular or with minute, nearly sessile, barely perceptible glands

2. Leaves slightly auriculate but sessile or nearly so at the base, upper cauline leaves strongly reduced in size from midstem; phyllaries white indurated and enervate at the

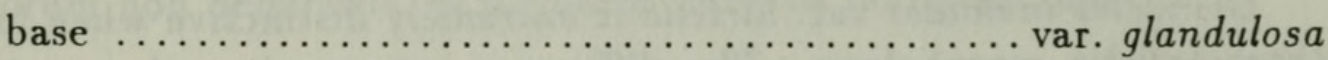

$2^{\prime}$ Leaves thin whitish and strongly clasping at the very base, upper cauline leaves little reduced in size from midstem; phyllaries herbaceous and 3 nerved at the base $\ldots \ldots \ldots \ldots \ldots \ldots \ldots \ldots \ldots \ldots \ldots \ldots \ldots$ var. latamplexa 
3. Stems moderately to densely villous; foliar teeth glandular and blunt at the apex; phyllaries strongly graduated, the inner erect, $6-8 \mathrm{~mm}$ long, the outer strongly reflexed; achenes with deep, transverse furrows at

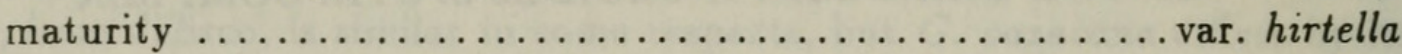

3. Stems very sparsely villous; foliar teeth indurated and sharp pointed at the apex; phyllaries subequal or weakly graduated, all more or less erect, $8-11 \mathrm{~mm}$ long; achenes smooth to weakly sculptured ...... var. inuloides

Grindelia inuloides Willd. var. glandulosa (Greenm.) Steyerm.

Grindelia inuloides Willd. var. glandulosa (Greenm.) Steyerm., Ann. Missouri Bot. Gard. 21:456. 1934. TYPE: MÉXICO. Hidalgo: Sierra de Pachuca, 13 Aug 1898, C.G. Pringle 6962 (HOLOTYPE: GH!; Isotypes: MO!,US). Grindelia glandulosa Greenm., Proc. Amer. Acad. Arts 34:575. 1899.

Hidalgo, Puebla, Michoacán, scattered in areas of high elevation; meadows, near pine, fir, or spruce; $2400-3050 \mathrm{~m}$; June-October.

In its most representative form, var. glandulosa is very distinctive. The glandular vestiture is dense, with very few eglandular hairs present. Lightly glandular plants, however, can be found among those of var. hirtella as well as scattered through the eastern range of var. inuloides.

Grindelia inuloides Willd. var. hirtella (Robinson \& Greenm.) Nesom

Grindelia inuloides Willd. var. hirtella (Robinson \& Greenm.) Nesom, comb. nov. BASIONYM: Grindelia squarrosa (Pursh) Dun. var. hirtella Robinson \& Greenm., Amer. J. Sci. 50:153. 1895. TYPE: MÉXICO. Oaxaca: hills, Las Sedas, $6000 \mathrm{ft}, 16$ Aug 1894, C.G. Pringle 4805 (HOLOTYPE: US; Isotype: MO!).

Central to northwest Oaxaca; calcareous slopes, fields, roadsides; ca 1200$1800 \mathrm{~m}$; January-September.

Grindelia inuloides var. hirtella is characterized by villous stem pubescence, blunt, glandular, foliar teeth, strongly reflexed outer phyllaries with a glandular groove on the distal adaxial surface and sculptured achenes. It is similar in aspect to var inuloides, which differs in smooth achenes, sharp pointed, nonglandular foliar teeth and erect, more herbaceous phyllaries.

Grindelia inuloides var. hirtella is extremely distinctive when found in its characteristic morphology. The difference between it and var. inuloides is greater than between a number of other closely related Mexican taxa recognized as distinct species. Particularly in northern Oaxaca (Map 5), however, the intermediates are too numerous over a wide area to allow the two taxa to be maintained as separate species. 
Grindelia inuloides Willd. var. inuloides

Grindelia inuloides Willd., Ges. Naturf. Freunde Berlin Mag. 1:261. 1807. TYPE: MÉXICO. Grown in Europe from seeds sent from México by Sesse (B, photo-MO!). According to Steyermark (1934), the leaves of the type have "margins with close sharp serrulations," which indicates that it was collected north of Oaxaca, primarily the range of var. hirtella.

Grindelia angustifolia Kunth, Nov. Gen. \& Sp. 4 [folio]:245. 1818; 4 [quarto]:309. 1820. TYPE: MÉXICO. Michoacán: Prope Valladolid de Michoacán et Pazcuaro, Humboldt \& Bonpland s.n. (HOLOTYPE: P fiche!). See Steyermark (1934) for additional synonyms.

Northern Jalisco, Guanajuato, Michoacán, Querétaro, Hidalgo, México, Puebla and northern Oaxaca; cultivated areas, pine-oak woods; $1800-2250 \mathrm{~m}$; (June-)July-October.

As I have treated it, Grindelia inuloides is the most variable of all the Mexican species. Even within var. inuloides, a great deal of variability remains and almost certainly will form the basis for segregation of additional taxa in the future. For example, a distinctive form with the upper cauline leaves reduced to a long series of linear-filiform peduncular bracts occurs from Zitácuaro to Morelia, Michoacán. These plants also have very strongly graduated phyllaries. Plants with basal branching and very broad, lacerate-ciliate phyllaries are found in México, southern Hidalgo and Puebla. Plants with strongly decurrent leaves appear to be relatively common in Puebla. The plants in northeastern Jalisco have more strongly scabrous foliar margins and longer ligules than elsewhere in the range of the species.

Grindelia inuloides Willd. var. latamplexa Nesom

Grindelia inuloides Willd. var. latamplexa Nesom, var. nov. TYPE: MÉXICO. Querétaro: $2.7 \mathrm{~km}$ SW of Pinal de Amoles on Hwy 120, 1.7 $\mathrm{km} \mathrm{NE}$ of the SARH forestry fire station, 27 Dec 1980, J.M. Canne 1941 with D.W. Woodland (HOLOTYPE: F!).

Grindelia inuloidi Willd. var. glandulosae (Greenm.) Steyerm. similis sed basibus foliorum valde amplectentibus, foliis caulium superorum non deminutis, et phyllariis nervatis herbaceis differt.

Taprooted annuals or biennials, with stems, leaves and phyllaries densely stipitate glandular. Stems $25-40 \mathrm{~cm}$ tall, dark purple, glandular and moderately to densely villous, with $2-4$ branches on the upper half. Basal leaves persistent, $10-15 \mathrm{~cm}$ long, with a basally dilated, multinerved petiole; cauline leaves $3-6 \mathrm{~cm}$ long, only slightly reduced in size upwards, the base broadly 
clasping, whitish, with 3-5 veins entering in parallel from the stem and continuing independently and more or less palmately into the blade, the teeth sharp pointed, not glandular, the lamina glandular and hirtellous to sparsely short pilose. Heads 15-20 mm wide; phyllaries relatively evenly herbaceous, all series erect and of nearly even length, narrowly triangular, 3 nerved at least on the lower portion. Ray flowers 25-50. Achenes apparently monomorphic, mature morphology not observed; pappus awns smooth edged.

Querétaro, in the vicinity of Pinal de Amoles; roadsides, banks, in both oak and pine woods; $2300-2400 \mathrm{~m}$; November-February(-probably later).

Additional collections examined: MÉXICO. Querétaro. $1.5 \mathrm{mi}$ W of Pinal de Amoles, 11 Nov 1976, Turner 76-13(LL); $6.5 \mathrm{mi}$ S of Pinal de Amoles along Hwy 120, 16 Jan 1977, Urbatsch \& Pridgeon 3038 (LL).

The three collections of these distinctive plants have all come from the immediate vicinity of Pinal de Amoles, Querétaro, on the northern periphery of the range of the species (Map 5). They are recognized by their densely glandular vestiture, villous stems, cauline leaves with broadly clasping, multinerved bases and herbaceous, narrowly triangular, even length, basally 3 nerved phyllaries. The cauline leaves are relatively unreduced in size upwards, with some of them immediately subtending the heads as foliar bracts. These plants may deserve specific rank, but the features that characterize them can be found, although not coherently, through the range of var. inuloides.

The populations of Grindelia inuloides in northeastern México

Although they are restricted in distribution and far disjunct from the primary range of the species (Maps 5 and 6), there is very little to distinguish the plants of Grindelia inuloides in Nuevo León from those of var. inuloides in south central México. The northern plants are consistently perennial with shorter, decumbent-ascending stems, but similar sized plants with a similar habit occur in the south as well. They tend to have slightly smaller heads and the inner and outer series of phyllaries exhibit the same extreme variability in graduation of length as seen in the more southern plants.

While true Grindelia inuloides can be recognized among these northern forms, there is a closely related taxon from that area that I believe warrants formal recognition as a species.

Grindelia hintoniorum Nesom, sp. nov. TYPE: MÉXICO. Nuevo León: Mpio. Galeana , E of Pablillo, oak woods, 1940 m, 15 May 1984, Hinton, et al. 18666 (HOLOTYPE: TEX!; Isotypes: NY!,WIS!,others to be distributed - MEXU?).

Grindelia inuloidi Willd. similis sed caulibus brevioribus, vestimento dense stipitati-glanduloso, et foliis decurrentibus differt. 
Perennial herbs with many ascending-decumbent unbranched stems 5-15 $\mathrm{cm}$ long from the base, apparently taprooted. Stems, leaves and phyllaries densely stipitate glandular from top to bottom of plant, the stems also sparsely to very sparsely villous-hirsute, leaves and phyllaries mostly without eglandular hairs except along the veins and margins. Basal leaves spatulateoblanceolate, lower and midcauline oblong-oblanceolate, 10-22 mm long, 4-6 mm wide, clasping, decurrent for $0.5-2.0 \mathrm{~mm}$, with $10-22$ pairs of sharp indurated but not aristate teeth, strongly reduced to linear, leafy bracts just beneath the heads. Heads $10-12 \mathrm{~mm}$ wide, solitary, phyllaries evenly and narrowly triangular-lanceolate, white indurated at the base, gradually becoming herbaceous upwards, in 5-6 weakly graduated to subequal series, the innermost 7-8 mm long, mostly erect, with loose or spreading, minutely aristate apices. Ray flowers 19-34, the corollas 9-11 mm long. Disc corollas 4.5-5.0 mm long, abruptly ampliate above the tube. Mature achenes not seen; pappus awns 2 , smooth edged, equal or slightly longer than the disc corollas.

Grindelia hintoniorum is known from a single remarkable collection. On the three sheets cited, it is represented by a large number (ca 35) of stems broken off at the base. All are densely stipitate glandular from top to bottom. In the small size of its stems, leaves, heads and ligules, $G$. hintoniorum is most similar to and probably most closely related to forms of $G$. inuloides from Nuevo León. A number of collections of the latter from the area of Pablillo, however, are typical for the species and show nothing of the densely stipitate glandular vestiture displayed by all plants of $G$. hintoniorum (Map 6).

\section{Other species related to Grindelia inuloides}

Grindelia greenmanii Steyerm., the common, high elevation species of Coahuila and Nuevo León (Map 6), appears to be only distantly related to the other species of northeastern México but more closely to the $G$. inuloides complex s. lat. It has densely stipitate glandular vegetative parts, very large leaves and heads, and herbaceous, subequal phyllaries. Rather than a taproot, it produces thick, lateral rhizomes.

Grindelia palmeri Steyerm., a relatively narrow endemic of the mountains east of Cd. San Luis Potosí (Map 5), has been identified as G. inuloides. It differs from $G$. inuloides in its more crowded cauline leaves that are only slightly reduced upwards and that are oblong with rounded apices and blunt, gland tipped teeth. This species does not appear to be as highly morphologically differentiated from $G$. inuloides as $G$. inuloides var. hirtella, but $G$. palmeri is allopatric with $G$. inuloides and no intermediates between them have been seen. 


\section{A NEW SPECIES OF GRINDELIA FROM NUEVO LEÓN}

Grindelia vetimontis Nesom, $s p$. nov. TYPE: MÉXICO. Nuevo León: Mpio. Zaragoza, Cerro del Viejo, $15 \mathrm{mi} \mathrm{W}$ of Dulces Nombres, rocky slopes in open pine forest, $3330 \mathrm{~m}, 18 \mathrm{Aug} 1948$, F.G. Meyer \& D.J. Rogers 2988 (HOLOTYPE: MO!; Isotype: F!).

Grindelia greenmanii Steyerm. similis rhizomatibus, foliis glandulosis, et acheniis monomorphis laevibus valde compressis sed differt caulibus eglandulosis, foliis superis caulinis ovati-oblongis non deminutis, capitulis minoribus, et phyllariis externis 3-5 nervibus inuduratis ad bases.

Perennials from a thick rhizome. Stems $3-5 \mathrm{dm}$ tall, sparsely to moderately villous, eglandular or very sparsely glandular just below the heads. Leaves densely invested with minute, sessile or barely stipitate resin glands, intermixed with sparse villous-hirtellous hairs; basal leaves persistent, ellipticoblanceolate, the cauline ovate-oblong, clasping but not basally ampliate, 15-30 mm long 10-12 mm wide, relatively even sized and of constant shape upwards, the teeth eglandular, sharp pointed, indurated at the tip but not spinulose. Heads $15-18 \mathrm{~mm}$ wide, immediately subtended by several, large, leaf like bracts; phyllaries ovate-lanceolate, conspicuously 3-5 nerved, with the lower $2 / 3-3 / 4$ white indurated, the outer gradually tapered to a herbaceous, spreading-reflexing tip, the inner sharply constricted at the very apex. Ray flowers 22-24. Disc corollas $5 \mathrm{~mm}$ long. Achenes monomorphic, obovate, 2.8$3.2 \mathrm{~mm}$ long, strongly compressed with 2 lateral nerves, the walls smooth or with several, faint, longitudinal nerves; pappus awns $1-2$, very slender, smooth edged.

Known only from the type collection (Map 6).

Grindelia vetimontis is similar to G. greenmanii, G. obovatifolia and $G$. robinsonii in its rhizomatous habit, foliar teeth with sharp, indurated points and very slender pappus awns. It is similar to the first and probably most closely related to it in its glandular leaves, and monomorphic, smooth and strongly compressed achenes, but different in its eglandular stems, differently shaped and unreduced upper cauline leaves, smaller heads, and nervate, basally white indurated outer phyllaries. It is similar to the latter two in its leaf shape and nervate phyllaries, but different in its prominent foliar capitular bracts, broader phyllaries that are apically more abruptly acute and monomorphic (vs. dimorphic) achenes. 


\section{ACKNOWLEDGMENTS}

I thank Billie Turner and Andrew McDonald for their comments on the manuscript and I appreciate loans of specimens from F, GH, SMU, US and WIS. I also credit Turner for first and correctly recognizing the distinctive pattern of morphological and geographical variation within Grindelia microcephala.

\section{LITERATURE CITED}

Correll, D.S. \& M.C. Johnston. 1970. Manual of the Vascular Plants of Texas. Texas Research Foundation, Renner, Texas.

Dunford, M.P. 1970. Interchange heterozygosity in diploid interspecific hybrids in Grindelia (Compositae). Amer. J. Bot. 57:623-628.

1986. Chromosome relationships of diploid species of Grindelia (Compositae) from Colorado, New Mexico, and adjacent areas. Amer. J. Bot. 73:297-303.

Great Plains Flora Association. 1977. Atlas of the Flora of the Great Plains. Iowa State Univ. Press, Ames.

Harrington, H.D. 1954. Manual of the Plants of Colorado. Sage Books, Denver, Colorado.

Johnston, M.C. 1970. Compositae. Pp. 1523-1736, in Correll, D.S. \& M.C. Johnston. Manual of the Vascular Plants of Texas. Texas Research Foundation, Renner, Texas.

Kearney, T.H. \& R.H. Peebles. 1951. Arizona Flora. Univ. California Press, Berkeley.

Kovanda, M. 1972. Somatic chromosome numbers for some Astereae. Rhodora $74: 102-106$.

Martin, W.C. \& C.R. Hutchins. 1981. A Flora of New Mexico. J. Cramer, Vaduz.

McVaugh, R. 1984. Grindelia. pp. 468-473 in Flora Novo-Galicia 12 (Cr positae). 
Muller, C.H. \& K.K. Muller. 1980. "Botanical Notes," in Berlandier, J.L. Journey to Mexico during the years 1826 to 1834. Texas State Historical Association, Austin, Texas.

Pinkava, D.J. \& D.J. Keil. 1977. Chromosome counts of Compositae from the United States and Mexico. Amer. J. Bot. 64:680-686.

Powell, A.M. \& B.L. Turner. 1963. Chromosome numbers in the Compositae. VII. Additional species from the southwestern United States and Mexico. Madroño 17:128-140.

Raven, P.H., O.T. Solbrig, D.W. Kyhos \& R. Snow. 1960. Chromosome numbers in Compositae. I. Astereae. Amer. J. Bot. 47:124-132.

Rzedowski, J. 1985. Compositae. Pp. 1445-1669. In Flora Fanerogamica del Valle de México. Instituto de Ecológia, México, D.F.

Schaack, C.G. 1983. In IOPB chromosome number reports LXXX. Taxon 32:509. 1983.

Semple, J.C. 1985. Chromosome number determinations in fam. Compositae tribe Astereae. Rhodora 87:517-527.

Steyermark, J.A. 1934. Studies in Grindelia. II. A monograph of the North American species of the genus Grindelia. Ann. Missouri Bot. Gard. 21:433-608.

Turner, B.L. \& W.L. Ellison. 1960. Chromosome numbers in the Compositae. I. Chromosome counts for 25 species of Texas Compositae including 6 new generic reports. Texas J. Sci. 12:146-151.

Turner, B.L., Beaman, J.H. \& H.F.L. Rock. 1961. Chromosome numbers in the Compositae. V. Mexican and Guatemalan species. Rhodora 63:121129.

Welsh, S.L. 1983. Utah flora: Compositae (Asteraceae). Great Basin Nat. 43:179-357.

Whitaker, T.W. \& J.A. Steyermark. 1935. Cytological aspects of Grindelia species. Bull. Torrey Bot. Club 62:69-73. 


\section{$2 \mathrm{BHL}$ Biodiversity Heritage Library}

Nesom, G L. 1990. "Studies in the systematics of Mexican and Texan Grindelia (Asteraceae: Astereae." Phytologia 68, 303-332.

https://doi.org/10.5962/bhl.part.5803.

View This Item Online: https://www.biodiversitylibrary.org/item/47092

DOI: https://doi.org/10.5962/bhl.part.5803

Permalink: https://www.biodiversitylibrary.org/partpdf/5803

\section{Holding Institution}

New York Botanical Garden, LuEsther T. Mertz Library

\section{Sponsored by}

The LuEsther T Mertz Library, the New York Botanical Garden

\section{Copyright \& Reuse}

Copyright Status: In copyright. Digitized with the permission of the rights holder.

Rights Holder: Phytologia

License: http://creativecommons.org/licenses/by-nc-sa/3.0/

Rights: https://biodiversitylibrary.org/permissions

This document was created from content at the Biodiversity Heritage Library, the world's largest open access digital library for biodiversity literature and archives. Visit BHL at https://www.biodiversitylibrary.org. 